\title{
Building a Better Halide Receptor. Optimum Choice of Spacer, Binding Unit, and Halosubstitution
}

\author{
Binod Nepal and Steve Scheiner* \\ Department of Chemistry and Biochemistry \\ Utah State University \\ Logan UT 84322-0300
}

\begin{abstract}
Quantum calculations are used to measure the binding of halides to a number of bipodal dicationic receptors, constructed as a pair of binding units separated by a spacer group. A number of variations are studied. A H atom on each binding unit (imidazolium or triazolium) is replaced by Br or I. Benzene, thiophene, carbazole, and dimethylnaphthalene are considered as spacer groups. Each receptor is paired with halides $\mathrm{F}^{-}, \mathrm{Cl}^{-}, \mathrm{Br}^{-}$, and $\mathrm{I}^{-}$. I-substitution on the binding unit yields a large enhancement of binding, as much as 13 orders of magnitude; a much smaller increase occurs for bromosubstitution. Imidazolium is a more effective binding agent than is triazolium. Benzene and dimethylnaphthalene represent the best spacers, followed by thiophene and carbazole. $\mathrm{F}^{-}$binds much more strongly than do the other halides which obey the order $\mathrm{Cl}^{-}>\mathrm{Br}^{-}>\mathrm{I}^{-}$.

*email: steve.scheiner@usu.edu
\end{abstract}

keywords: M06-2X; molecular electrostatic potential; charge transfer; bite angle 


\section{INTRODUCTION}

Due to the importance of selective and efficient binding of anions, there has been a growing body of work aimed at understanding the fundamentals of this process. The majority of anion receptor systems make use of $\mathrm{H}$-bonds (HBs) ${ }^{[1-4]}$. On the other hand, there has been renewed interest in the idea that the bridging proton of a HB can be replaced by a halogen atom. The resulting halogen bond (XB) is enabled by a small region of positive electrostatic potential on the halogen atom $\mathrm{X}$, directly opposite the $\mathrm{C}$ - $\mathrm{X}$ bond, that is able to interact attractively with an approaching negatively charged species. The replacement of $\mathrm{H}$ by $\mathrm{X}$ does not necessarily lead to weakening of the bond, and in fact XBs can be stronger than their HB congeners in many cases ${ }^{[5-12]}$.

And indeed, work in recent years has shown that the HBs of anion receptors can be replaced by XBs with interesting and useful results ${ }^{[13-19]}$. Many of the relevant binding agents have been bipodal in nature, with two different halogen atoms connecting to the anion via XBs. These interactions have typically been further strengthened by the presence of positive charge on the receptor. Most of the bidentate anion receptors that have been synthesized and tested to this point contain certain features in common ${ }^{[13,16,18,20-}$ 42]. The heterocyclic imidazolium and triazolium rings are most frequently used to bind directly to the halide. These rings are often modified by replacement of an $\mathrm{H}$ atom by a halogen, most commonly $\mathrm{I}$. The pair of binding units are placed on opposite ends of an aromatic spacer group. Most typically used for this purpose are benzene, thiophene, carbazole, and naphthalene derivatives.

Taking several examples from just this past year, Tepper et al ${ }^{[43]}$ studied systems employing halosubstituted triazolium units separated by benzene and thiophene. The latter resulted in significantly weaker binding of halides. The authors explained this difference in terms of "bite angles" which describe the relative orientations of the two halogen bonds to the bound halide. Mullaney et al ${ }^{[37]}$ separated a pair of triazoliums by a carbazole spacer and found that I-substitution on the triazoliums strongly enhanced the receptor's ability to bind halides. Jungbauer and Huber ${ }^{[28]}$ placed both triazoliums and imidazoliums onto a phenyl spacer, and observed that halosubstitution imparted catalytic activity to these receptors via halogen bonds.

While data is rapidly building concerning the construction of effective halide receptors, there is still little in the way of a systematic comparison of the various combinations of binding unit, halosubstitution, or spacer group. How is the binding of a halide affected by each factor, alone or in combination with the others? What combination might make for the strongest binding of one halide over the others? Do halogen bonds truly represent a stronger mode of binding a halide than H-bonds, and if so by how much? What are the fundamental properties that influence the ability of a receptor to bind a halide: electronic, geometric, 
etc? In short, what particular set of properties might make for the optimal halide receptor? Answers to these questions will assist in the rational design of new and more effective receptors.

This work applies quantum calculations to attempt to answer these questions. In order to do so, a large variety of receptors are constructed. As illustrated in Scheme I, each is composed of a pair of cationic binding units, attached to either end of a spacer group. In keeping with earlier work, imidazolium and 1,2,3-triazolium are considered as binding groups. One $\mathrm{H}$ atom of each binding unit is replaced in turn by $\mathrm{Br}$ and I, so as to convert H-bonds to the supposedly stronger halogen bonds. Four different spacer groups were evaluated: benzene, thiophene, carbazole, and dimethylnaphthalene, again in keeping with prior experimental work. Each such bidentate receptor was paired with $\mathrm{F}^{-}, \mathrm{Cl}^{-}, \mathrm{Br}^{-}$, and $\mathrm{I}^{-}$, so as to elucidate the preferences for one halide over another. In order to provide a thorough and systematic evaluation of all combinations, a total of 96 different receptor-halide pairs were computed and compared with one another.

\section{COMPUTATIONAL METHODS}

All the calculations were carried out with the M06-2X DFT functional ${ }^{[44]}$ in conjunction with the augcc-pVDZ basis set, within the framework of the Gaussian-09 ${ }^{[45]}$ set of programs. For the heavy atoms $\mathrm{Br}$ and I, aug-cc-pVDZ-PP pseudopotentials were taken directly from the EMSL library ${ }^{[46,47]}$. This level of theory is appropriate for this task, as evident by previous work by others ${ }^{[48-57]}$ and very recently by ourselves in dealing with very similar sorts of systems ${ }^{[58]}$. The geometries of the complexes were fully optimized without any restriction. Only the optimized geometries with all positive vibrational frequencies were taken into consideration. The binding energy, $\mathrm{E}_{\mathrm{b}}$, of each halide with its receptor was calculated as the difference between the energy of the complex and the sum of the energies of separately optimized monomers. Each binding energy was corrected for basis set superposition error using the counterpoise ${ }^{[59]}$ procedure. To account for solvent effects, the polarizable conductor calculation model (CPCM) was applied ${ }^{[60]}$, with water as the solvent. The molecular electrostatic potential map was carried out with WFA-SAS program ${ }^{[61]}$ and charge transfer assessed via the Natural Bond Orbital (NBO) technique ${ }^{[62]}$.

\section{RESULTS}

\section{Energetics}

The binding energies of the halides with the various anion receptors are presented in Table 1 . The binding unit, whether imidazolium or triazolium, is listed in the first row, followed in the next row by the identity of the spacer. The next row indicates the nature of the two atoms bound directly to the halide, $\mathrm{H}$, $\mathrm{Br}$, or I. Selected geometries of the complexes with iodide are illustrated in Figs 1 and 2, with all structures displayed in the Supplementary Information. In most cases, the halide sits midway between the two binding atoms of the receptor, but in certain cases, indicated by the asterisk in Table 1, the halide is 
asymmetrically positioned. One such example may be seen in Fig $2 \mathrm{~b}$ where the iodide ion is positioned more closely to the H-bonding triazolium than to the other.

There are a number of interesting trends in the energetics of Table 1, which are visualized in Figs 3-5. Fig 3 represents the $\mathrm{H}$-bonding receptors, while the $\mathrm{Br}$ and I-binding species are illustrated respectively in Figs 4 and 5. Color coding, e.g. green for $\mathrm{F}^{-}$, identifies the halide, and solid and broken lines represent the binding species, solid for imidazolium and broken for triazolium. One can see immediately that $\mathrm{F}^{-}$(green curves) is bound considerably more strongly than the other anions: $\mathrm{F}^{-}>>\mathrm{Cl}^{-}>\mathrm{Br}^{-}>\mathrm{I}^{-}$. There is a minor disruption of this pattern for the H-bonding bis-triazolium system with thiophene and carbazole spacer, where $\mathrm{I}^{-}$is bound only slightly more strongly than $\mathrm{Br}^{-}$. With respect to $\mathrm{H}$-bonding receptors in Fig 3, imidazolium-based receptors (solid curves) are superior to triazolium. This distinction is particularly noticeable for fluoride which is favored by imidazolium by as much as $4 \mathrm{kcal} / \mathrm{mol}$, smaller differences are observed for the larger halides.

The shapes of the solid and dashed lines are similar for each color. In other words, the variation of the binding energies of the halides with different spacers is similar for triazolium and imidazolium based systems. For example, both triazolium and imidazolium based receptors display minima at the dimethylnaphthalene spacer and maxima at the benzene spacer when binding $\mathrm{F}^{-}$. In contrast for the larger halides, thiophene represents the spacer group with the lowest binding energy, leaving benzene and dimethylnaphthalene as the best spacers.

There appears to be some connection between these trends and the geometries of the bound complexes. For example, the particularly strong binding of $\mathrm{F}^{-}$to the benzene spacer may be related to its ability to form a pair of strong symmetrical $\mathrm{HBs} \mathrm{Cl}^{-}$, on the other hand, engages in this double $\mathrm{H}$-bonded arrangement only with benzene and dimethylnaphthalene, to which it is most strongly bound. Considering the $\mathrm{Br}^{-}$and $\mathrm{I}^{-}$ halides, which are located symmetrically for most spacers, there is a clear correlation between the binding energy and lengths of the HBs, as the shortest HBs are observed for benzene and dimethylnaphthalene, which are also most strongly bound.

Fig 4 is analogous to Fig 3, but replaces the $\mathrm{H}$ atoms on the binding units by Br. As in Fig 3, $\mathrm{F}^{-}$binds much more strongly than do the other halides. The solid lines again lie above the dashed lines (with certain exceptions), indicating imidazolium based systems bind more strongly than triazolium. The principal exception occurs with the carbazole spacer where there is little distinction for the larger halides, and the triazolium is actually preferred for $\mathrm{F}^{-}$. There are other differences as well. While H-bonding dimethylnaphthalene was a poor spacer for $\mathrm{F}^{-}$, it is quite good when engaging in a Br-bond with fluoride. Overall, for those receptors employing Br-bonds, benzene and dimethylnaphtalene spacers form the 
strongest interactions with halides, with little sensitivity to the nature of the binding agent, imidazolium or triazolium; thiophene and carbazole are poorer choices.

Replacement of $\mathrm{Br}$ on the imidazolium and triazolium species by I leads to the binding energies displayed in Fig 5. The patterns are similar in some respects with a few important distinctions. In the first place, the I-substituted receptors bind more strongly than their Br congeners. As in the other cases, the order of binding of the anions follows the familiar $\mathrm{F}^{-}>>\mathrm{Cl}^{-}>\mathrm{Br}^{-}>\mathrm{I}^{-}$pattern. As for Br, imidazoliumbased receptors are superior to triazolium, and the spacer that offers the weakest binding in most cases is carbazole, with benzene and dimethylnaphthalene the strongest. One interesting reversal occurs in the context of the carbazole spacer. Whereas $\mathrm{F}^{-}$is bound more strongly by triazolium than by imidazolium for the Br-substituted receptors, the opposite is true for I substitution. This reversal may be associated with the binding pattern in that $\mathrm{F}^{-}$is able to form two Br-bonds with triazolium, with length $2.50 \AA$, but only one with imidazolium. Note that there is little distinction between these two binding units for the other three halides.

Comparison of Figs 3-5, and inspection of Table 1, provides an important and overarching conclusion. The replacement of $\mathrm{H}$ on the binding units, whether imidazolium or triazolium, by I leads to a large increment in binding energy. These increases vary from $5 \mathrm{kcal} / \mathrm{mol}$ all the way up to $18 \mathrm{kcal} / \mathrm{mol}$. For example, the substitution of $\mathrm{H}$ by I on the bis-triazolium species with dimethylnaphthalene spacer raises the binding energy of $\mathrm{F}^{-}$from 10.0 to $27.6 \mathrm{kcal} / \mathrm{mol}$, nearly a three-fold magnification. This energetic change would correspond to an enhancement in the binding constant by an enormous 13 orders of magnitude. The enhancements are only slightly less dramatic for the other halides. Considering the same pair of receptors, the binding energy is doubled for $\mathrm{Cl}^{-}, \mathrm{Br}^{-}$and $\mathrm{I}^{-}$, representing increases of 8,7 , and $6 \mathrm{kcal} / \mathrm{mol}$ respectively. With respect to these magnifications in binding energy resulting from $\mathrm{H}$-to-I substitutions, the largest are generally associated with the thiophene and carbazole spacers; enhancements are also somewhat greater for triazolium than for imidazolium. The replacement of $\mathrm{H}$ by $\mathrm{Br}$, on the other hand, results in smaller increases in the binding energy, less than $3 \mathrm{kcal} / \mathrm{mol}$ in most cases.

\section{$\underline{\text { Geometries }}$}

One might anticipate a natural relationship to exist between the strength of the binding and the distance between the halide and the receptor. These distances are reported in Table 2, and one must recall that the halide takes up one of two positions. In the majority of cases, the halide is centrally placed between the two bonding atoms, whether $\mathrm{H}, \mathrm{Br}$, or I. But in a number of other cases, most commonly with the small $\mathrm{F}^{-}$ anion, the halide is asymmetrically positioned, much closer to one binding atom than the other. In these cases, indicated by an asterisk in Table 2, it is the shorter of the two distances that is displayed. 
There are several overriding patterns in evidence. The interatomic length is consistent with the radius of the anion: $\mathrm{F}^{-}<\mathrm{Cl}^{-}<\mathrm{Br}^{-}<\mathrm{I}^{-}$. H-bonds are shorter than halogen bonds, with $\mathrm{Br}$ and $\mathrm{I}$ bonds similar to one another. These distances are fairly insensitive to the identity of the bonding unit, whether imidazolium or triazolium, although usually longer for the latter. With regard to spacer, the bond lengths are generally inversely correlated with the binding energies, i.e. shorter bonds are associated with stronger binding.

Both H-bond and halogen bonds strive toward linearity, deviations from which can quickly degrade their strength. While those complexes bearing a single $\mathrm{H}$ or halogen bond can more easily adopt a linear structure, the presence of a second such bond would cause a certain deformation in each, a cost of engaging in a second bond. It is thus natural that the multibonded systems, indicated by the asterisk in Table 3 , tend toward higher angles, closer to $180^{\circ}$. Beyond this pattern, one might note that stronger complexes are associated with more linear structures. For example, considering the benzene spacers in the first set of columns of Table 3, the $\mathrm{CH}^{\cdots} \mathrm{Y}^{-} / \mathrm{CX}^{\cdots} \mathrm{Y}^{-}$bond angles are more linear for the complexes with imidazolium species than triazolium, consistent with the stronger binding of the former. The bond length pattern is reversed for the carbazole spacers with $\mathrm{X}=\mathrm{Br}$, as is the binding energy.

There has been some thought in the literature ${ }^{[43]}$ that the binding energy might be related to a "bite

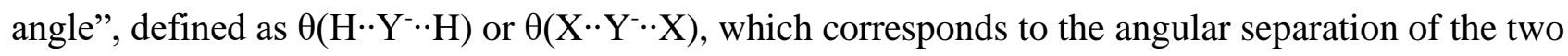
binding sites. These angles are displayed in Table 4 from which one may note certain trends. These angles are largest for the smallest anions: $\mathrm{F}^{-}>\mathrm{Cl}^{-}>\mathrm{Br}^{-}>\mathrm{I}^{-}$, which suggests that the binding atoms are furthest removed from one another for the larger halides. H-bonding angles are considerably larger than their

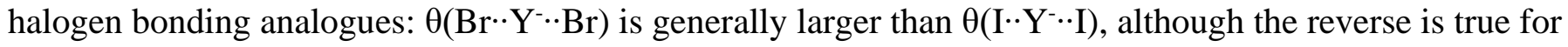
the benzene spacer. Concerning the binding species, there is no obvious large distinction between imidazolium and triazolium, although the latter has larger bite angles for the dimethylnaphthalene spacer. One may conclude that the bite angles are not well correlated with the binding energies.

An alternate means of assessing the bite angle lies in the geometry of the receptor, prior to formation of a complex with an anion. One can project the $\mathrm{CH} / \mathrm{CX}$ bonds of the two binding agents toward a meeting point, P. P might be considered the ideal binding position of an anion in the sense that it would lead to perfectly linear $\mathrm{CH}^{*} \cdot \mathrm{Y}^{-}$bonds, with no distortion required in the receptor. On the other hand, placement of a halide at point $\mathrm{P}$ might lead to unfavorably long $\mathrm{H} /$ halogen bonds, which would counter the favorable angular aspects, so one might anticipate the optimal placement of the halide to result from a compromise between these two factors.

The $\theta(\mathrm{H} \cdot \mathrm{P} \cdot \cdot \mathrm{H}) / \theta(\mathrm{X} \cdot \mathrm{P} \cdot \cdot \mathrm{X})$ angles of this idealized position for the various uncomplexed receptors are reported in Table 5, from which it may be seen first that there is a good deal of variability. For the imidazolium systems, the H-bonding bite angles are considerably larger than for the halogens, but this 
distinction is lessened for triazolium. For all four spacers, the angle is smaller for triazolium than for imidazolium for $\mathrm{X}=\mathrm{H}$, but the reverse is true for $\mathrm{Br}$ and $\mathrm{I}$ for carbazole and dimethylnaphthalene spacers. There is a certain degree of correlation between bite angles and the binding energies. In the H-bonding receptors, for example, the larger bite angles for the imidazolium species are reflected in their higher binding energies with the various halides, and the weakest binding with the thiophene spacer (for all but fluoride) mimics the smallest angles. In the case of the halogen-bonding receptors, the large bite angles for the dimethylnaphthalene spacer is consistent with the generally strong binding energies. However, despite certain correlations, the bite angles of the uncomplexed receptors provide only a rough estimate of the strength of binding with the halides.

Various steric interactions prevent the two terminal bonding species from being coplanar with the central spacer unit. The nonplanarity can be quantitated via the dihedral angle between the planes of these two species. These dihedral angles are reported in Table 6 where the first row of each section corresponds to the nonplanarity in the uncomplexed receptor. In most cases, with the exception of the large dimethylnaphthalene spacer, the larger halogen atoms cause a greater nonplanarity than do the $\mathrm{H}$ atoms. With this same exception, the nonplanarity is larger for the imidazolium than for the triazolium terminal groups. The addition of the halide generally makes the receptor more planar. This reduction of the dihedral angle is most noticeable for $\mathrm{F}^{-}$. For the halogen-bonding receptors, the $\mathrm{Cl}^{-}, \mathrm{Br}^{-}$and $\mathrm{I}^{-}$halides all induce very similar changes, but there is greater sensitivity for the H-bonding receptors, with I- yielding the greatest nonplanarity.

\section{Electronic Properties}

It is natural to expect that the interaction of an anion with a dication will be dominated by electrostatic effects. The $\mathrm{X}$ atom positions, whether $\mathrm{X}=\mathrm{H}, \mathrm{Br}$, or I, mark the location of a maximum in the molecular electrostatic potential (MEP) surrounding the receptor. The value of the MEP at this point is indicated in Table 7 for each of the various receptors. In all cases, this potential is largest for $\mathrm{X}=\mathrm{H}$; the values for the two halogens are fairly similar to one another. The largest values occur for the benzene spacer and the smallest for carbazole. For the benzene and thiophene spacers, the MEP is more positive for imidazolium than for triazolium, although this distinction is largely absent for the other two spacers. These patterns for the maximum MEP match to a certain degree the binding energies for the halogen-bonding receptors, although the correlation is far from perfect.

In addition to Coulombic attraction, the halide can be anticipated to transfer a good deal of charge to the dication receptor. The energetic consequence of this transfer can be assessed via the second-order perturbation energy $\mathrm{E}(2)$ within the natural bond orbital (NBO) formalism. These quantities corresponding to the transfer from the halide to the $\mathrm{CH} / \mathrm{CX} \sigma^{*}$ antibonding orbitals are presented in Table 8. Graphical 
representation of this data in Figs S2-S5 show strong resemblance to the binding energies in Figs 3-5. Taking the H-bonding receptors as an example, with the exception of the fluoride data, the E(2) patterns for the other three halides look very much like the binding energies, with a minimum for thiophene, and maxima for benzene and methylnaphthalene. Moreover, the imidazolium shows both larger E(2) and stronger binding than does the triazolium. The similarities between $\mathrm{E}(2)$ and binding energy patterns are even stronger for the $\mathrm{Br}$ and I-bonding receptors. Also, the similarities intensify further if one ignores the asymmetric complexes, containing only a single $\mathrm{H}$ or halogen bond. It may be concluded then that there is a high degree of charge transfer in these complexes, and that the amount of charge transfer correlates very well with the binding energy.

\section{SUMMARY AND DISCUSSION}

A wide array of dicationic receptors has been considered here. Both imidazolium and triazolium were tested as the species that bind directly to the anion. In addition to the $\mathrm{H}$ atoms on these groups which form $\mathrm{H}$-bonds to the halide, $\mathrm{Br}$ and I were examined as well, which engage in halogen bonds. Four different spacers were evaluated that separate the imidazolium/triazolium binding groups. And finally, four different halide anions were allowed to react with each of these different receptors. Altogether, a total of 96 different complexes were carefully compared with one another.

In nearly all cases, $\mathrm{F}^{-}$was found to bind much more strongly to the receptors than the other three halides, with the order $\mathrm{F}^{-}>>\mathrm{Cl}^{-}>\mathrm{Br}^{-}>\mathrm{I}^{-}$generally operational. Replacement of $\mathrm{H}$ on the binding unit by $\mathrm{I}$ leads to impressive increases in the binding energy, in some cases by as much as three-fold. Enhancements are also observed for bromosubstitution, albeit less dramatic. In many, but not all cases, the imidazolium was a more effective binding agent than triazolium, particularly when it engages in $\mathrm{H}$ rather than halogen bonds. In the case of the halogen-bonding receptors, benzene and dimethylnaphthalene seem to be the best spacers, followed by thiophene and then carbazole. Regarding geometries, there is a tendency for the halide to be symmetrically disposed between the two $\mathrm{H}, \mathrm{Br}$, or I atoms, but this is not always the case, especially for the small fluoride anions and for the H-bonding receptors.

These aforementioned differences cannot be well accounted for by consideration of the size of the spacer. For example, the two binding species, imidazolium or triazolium, are separated from one another by three atoms for both the benzene and thiophene spacers, yet the former is associated with generally stronger receptors. The largest separation, by seven atoms, occurs for the dimethylnaphthalene spacer, but it nonetheless is roughly equivalent to the much smaller benzene in terms of its efficacy.

Nor are other geometrical parameters good predictors of binding strength. The so-called bite angle which relates to the possible nonlinearity of the $\mathrm{H}$ or halogen bonds do not seem to correlate well with binding energies. The degree of planarity within the entire receptor-halide complex is quite variable but 
does not offer a useful predictor of binding strength. There is a certain degree of correlation between the binding energy and the positive electrostatic potential at the binding site of each receptor. The binding energy is more strongly correlated, however, with the charge transfer from the halide to the $\sigma^{*}$ antibonding orbital of the $\mathrm{CH} / \mathrm{CX}$ bonds to which it is connected.

In conclusion, the calculations point toward an optimal bipodal halide receptor. In the first place, the units ought to engage in a pair of halogen bonds to the halide, employing I as anchoring atom. Imidazolium appears to be a slightly better binding unit than triazolium. The best spacer is dimethylnaphthalene, with benzene a close second. Regardless of the receptor chosen, $\mathrm{F}^{-}$will bind much more strongly than the three heavier halides, as the binding energy decreases along with the halide atomic weight.

There are certain caveats concerning the data presented here. While the energies were computed in a simulated aqueous phase, the procedure does not include explicit interactions between the solute and each surrounding water molecule, so the data can be considered as only an approximation to a true aqueous solution. Nonetheless, it is expected that while the quantitative values might be altered via a more rigorous treatment of solvation, that the trends would persist. Secondly, the binding energies do not include the corrections that would equate to enthalpies. However, prior calculations of very similar systems ${ }^{[58]}$ have shown that the binding energies are in fact quite similar to $\Delta \mathrm{H}$ with all appropriate corrections included. The transition to free energies via incorporation of entropic effects would lead to less negative quantities, but again the patterns in $\Delta \mathrm{H}$ would likely be evident in $\Delta \mathrm{G}$ as well, with even little quantitative change, as in the previous study ${ }^{[58]}$.

There are a number of important caveats that must be stressed. First, the energetics computed in this work refer to the interaction energy of the pertinent halide with the dicationic receptor. As such, the energy required to separate each ion from its counterions or solvation shell prior to formation of the pertinent complex in solution has not been included. As a second important point, the values reported in the tables do not include entropic effects. Consequently, the energetics reported here cannot be considered an accurate indicator of the free energy arising from the full process of i) desolvation of counterions and ii) association of receptor and halide. Rather, the reported data are meant to stress the interaction energy between each receptor and halide, free of additional complicating factors.

Bearing these caveats in mind, one can draw further insights from previously reported experimental data. Bis-imidazolium-based anion receptors with benzene separator ${ }^{[21]}$ were synthesized by Caballero et al. Those with no halogen substituent did not discriminate between the various halides, while incorporation of $\mathrm{Br}$ led to a clear preference for $\mathrm{Br}^{-}$. Walter et al ${ }^{[22]}$ constructed receptors containing a pair of imidazolium cations separated by benzene. The measurements confirmed our conclusion that replacement 
of $\mathrm{H}$ by I leads to stronger bonding to halides, but also emphasized the importance of both entropic effects and solvent; the latter can obscure the inherent trends of the various halides. Another system also contained a pair of imidazoliums, this time with a dimethyl naphthalene spacer ${ }^{[24]}$. I-substituted receptors bound both $\mathrm{Br}^{-}$and $\mathrm{I}^{-}$rather strongly; the preference for one halide over the other could be reversed by removal of one of the I substituents. Calculated binding energies were in the same range as experimental values of $\Delta \mathrm{G}$, but did not accurately portray the relative binding strength of bromide and iodide, again pointing to the importance of entropy.

Using a pyridinium separator between a pair of triazoles, Langton et al ${ }^{[18]}$ found the replacement of $\mathrm{H}$ by I on the triazoles greatly enhanced their binding to halides in aqueous solution, by as much as two orders of magnitude. Their analysis led to the conclusion that whereas the halogen binding of iodide is dominated by enthalpy, it is entropy that drives the H-bonding process. A more recent study ${ }^{[37]}$ placed a pair of triazoliums on a carbazole spacer. Far superior binding of halides by the I-substituted receptors was observed, and the binding constants obeyed the $\mathrm{Cl}^{-}>\mathrm{Br}^{-}>\mathrm{I}^{-}$trend, consistent with our calculations. On the other hand, size complementarity comes into play in rotaxanes where $\mathrm{Br}^{-}$is bound most strongly. This finding leads to the idea that design of improved receptors must take into account not only intrinsic strength of various halogen bonds, but also the structural details of receptor-halide complexes.

\section{ACKNOWLEDGMENTS}

Computer, storage and other resources from the Division of Research Computing in the Office of Research and Graduate Studies at Utah State University are gratefully acknowledged.

\section{SUPPORTING INFORMATION}

Geometries of all optimized complexes are illustrated in Figs S1 and S2 of the Supplementary Information. Figs S3-S5 display NBO charge transfer energies. 


\section{REFERENCES}

[1] A. E. Hargrove, S. Nieto, T. Zhang, J. L. Sessler, E. V. Anslyn, Chem. Rev. 2011, 111, 6603-6782.

[2] J. P. Malerich, K. Hagihara, V. H. Rawal, J. Am. Chem. Soc. 2008, 130, 14416-14417.

[3] A. G. Doyle, E. N. Jacobsen, Chem. Rev. 2007, 107, 5713-5743.

[4] P. R. Schreiner, Chem. Soc. Rev. 2003, 32, 289-296.

[5] W. Zierkiewicz, D. C. Bieńko, D. Michalska, T. Zeegers-Huyskens, J. Comput. Chem. 2015, 36, 821-832.

[6] P. Deepa, B. V. Pandiyan, P. Kolandaivel, P. Hobza, Phys. Chem. Chem. Phys. 2014, 16, $2038-$ 2047.

[7] U. Adhikari, S. Scheiner, J. Phys. Chem. A 2012, 116, 3487-3497.

[8] J. P. Anable, D. E. Hird, S. L. Stephens, D. P. Zaleski, N. R. Walker, A. C. Legon, Chem. Phys. Lett. 2015, 625, 179-185.

[9] P. Politzer, J. S. Murray. In Noncovalent Forces; Scheiner, S., Ed.; Springer: Dordrecht, Netherlands, 2015, p 357-389.

[10] S. Scheiner, CrystEngComm 2013, 15, 3119-3124.

[11] A. Bauzá, D. Quiñonero, P. M. Deyà, A. Frontera, CrystEngComm 2013, 15, 3137-3144.

[12] U. Adhikari, S. Scheiner, Chem. Phys. Lett. 2012, 532, 31-35.

[13] B. Schulze, U. S. Schubert, Chem. Soc. Rev. 2014, 43, 2522-2571.

[14] S. Ghosh, M. K. Mishra, S. B. Kadambi, U. Ramamurty, G. R. Desiraju, Angew. Chem. Int. Ed. 2015, 54, 2674-2678.

[15] R. W. Troff, T. Mäkelä, F. Topić, A. Valkonen, K. Raatikainen, K. Rissanen, Eur. J. Org. Chem. 2013, 2013, 1617-1637.

[16] T. M. Beale, M. G. Chudzinski, M. G. Sarwar, M. S. Taylor, Chem. Soc. Rev. 2013, 42, 1667-1680.

[17] P. Metrangolo, G. Resnati, Science 2008, 321, 918-919.

[18] M. J. Langton, S. W. Robinson, I. Marques, V. Félix, P. D. Beer, Nat Chem 2014, 6, 1039-1043.

[19] J. Y. C. Lim, P. D. Beer, Chem. Commun. 2015, 51, 3686-3688.

[20] N. L. Kilah, M. D. Wise, C. J. Serpell, A. L. Thompson, N. G. White, K. E. Christensen, P. D. Beer, J. Am. Chem. Soc. 2010, 132, 11893-11895.

[21] A. Caballero, N. G. White, P. D. Beer, Angew. Chem., Int. Ed. Engl. 2011, 50, 1845-1848.

[22] S. M. Walter, F. Kniep, L. Rout, F. P. Schmidtchen, E. Herdtweck, S. M. Huber, J. Am. Chem. Soc. 2012, 134, 8507-8512.

[23] A. Caballero, F. Zapata, N. G. White, P. J. Costa, V. Félix, P. D. Beer, Angew. Chem. Int. Ed. 2012, 51, 1876-1880.

[24] F. Zapata, A. Caballero, N. G. White, T. D. W. Claridge, P. J. Costa, V. Félix, P. D. Beer, J. Am. Chem. Soc. 2012, 134, 11533-11541.

[25] F. Kniep, L. Rout, S. M. Walter, H. K. V. Bensch, S. H. Jungbauer, E. Herdtweck, S. M. Huber, Chem. Commun. 2012, 48, 9299-9301.

[26] L. C. Gilday, T. Lang, A. Caballero, P. J. Costa, V. Félix, P. D. Beer, Angew. Chem. Int. Ed. 2013, 52, 4356-4360.

[27] S. Chakraborty, R. Dutta, P. Ghosh, Chem. Commun. 2015, 51, 14793-14796.

[28] S. H. Jungbauer, S. M. Huber, J. Am. Chem. Soc. 2015, 137, 12110-12120.

[29] M. G. Chudzinski, C. A. McClary, M. S. Taylor, J. Am. Chem. Soc. 2011, 133, 10559-10567.

[30] M. G. Sarwar, B. Dragisic, E. Dimitrijevic, M. S. Taylor, Chem. Eur. J. 2013, 19, 2050-2058.

[31] F. Kniep, S. H. Jungbauer, Q. Zhang, S. M. Walter, S. Schindler, I. Schnapperelle, E. Herdtweck, S. M. Huber, Angew. Chem. Int. Ed. 2013, 52, 7028-7032.

[32] L. C. Gilday, N. G. White, P. D. Beer, Dalton Trans. 2013, 42, 15766-15773.

[33] A. Caballero, L. Swan, F. Zapata, P. D. Beer, Angew. Chem. Int. Ed. 2014, 53, 11854-11858.

[34] S. W. Robinson, C. L. Mustoe, N. G. White, A. Brown, A. L. Thompson, P. Kennepohl, P. D. Beer, J. Am. Chem. Soc. 2015, 137, 499-507.

[35] F. Zapata, A. Caballero, P. Molina, I. Alkorta, J. Elguero, J. Org. Chem. 2014, 79, 6959-6969. 
[36] J. M. Mercurio, R. C. Knighton, J. Cookson, P. D. Beer, Chem. Eur. J. 2014, 20, 11740-11749.

[37] B. R. Mullaney, B. E. Partridge, P. D. Beer, Chem. Eur. J. 2015, 21, 1660-1665.

[38] W. He, Y.-C. Ge, C.-H. Tan, Org. Lett. 2014, 16, 3244-3247.

[39] J. Y. C. Lim, M. J. Cunningham, J. J. Davis, P. D. Beer, Chem. Commun. 2015, 51, 14640-14643.

[40] S. M. Walter, F. Kniep, E. Herdtweck, S. M. Huber, Angew. Chem. Int. Ed. 2011, 50, 7187-7191.

[41] C. J. Serpell, N. L. Kilah, P. J. Costa, V. Félix, P. D. Beer, Angew. Chem. Int. Ed. 2010, 49, 53225326.

[42] M. G. Sarwar, B. Dragisic, L. J. Salsberg, C. Gouliaras, M. S. Taylor, J. Am. Chem. Soc. 2010, 132, 1646-1653.

[43] R. Tepper, B. Schulze, M. Jäger, C. Friebe, D. H. Scharf, H. Görls, U. S. Schubert, J. Org. Chem. 2015, 80, 3139-3150.

[44] Y. Zhao, D. G. Truhlar, Theor. Chem. Acc. 2008, 120, 215-241.

[45] M. J. Frisch, G. W. Trucks, H. B. Schlegel, G. E. Scuseria, M. A. Robb, J. R. Cheeseman, G. Scalmani, V. Barone, B. Mennucci, G. A. Petersson, H. Nakatsuji, M. Caricato, X. Li, H. P. Hratchian, A. F. Izmaylov, J. Bloino, G. Zheng, J. L. Sonnenberg, M. Hada, M. Ehara, K. Toyota, R. Fukuda, J. Hasegawa, M. Ishida, T. Nakajima, Y. Honda, O. Kitao, H. Nakai, T. Vreven, J. Montgomery, J. A., J. E. Peralta, F. Ogliaro, M. Bearpark, J. J. Heyd, E. Brothers, K. N. Kudin, V. N. Staroverov, R. Kobayashi, J. Normand, K. Raghavachari, A. Rendell, J. C. Burant, S. S. Iyengar, J. Tomasi, M. Cossi, N. Rega, J. M. Millam, M. Klene, J. E. Knox, J. B. Cross, V. Bakken, C. Adamo, J. Jaramillo, R. Gomperts, R. E. Stratmann, O. Yazyev, A. J. Austin, R. Cammi, C. Pomelli, J. W. Ochterski, R. L. Martin, K. Morokuma, V. G. Zakrzewski, G. A. Voth, P. Salvador, J. J. Dannenberg, S. Dapprich, A. D. Daniels, O. Farkas, J. B. Foresman, J. V. Ortiz, J. Cioslowski, D. J. Fox. Wallingford, CT, 2009.

[46] D. Feller, J. Comput. Chem. 1996, 17, 1571-1586.

[47] K. L. Schuchardt, B. T. Didier, T. Elsethagen, L. Sun, V. Gurumoorthi, J. Chase, J. Li, T. L. Windus, J. Chem. Infor. Model. 2007, 47, 1045-1052.

[48] A. D. Boese, ChemPhysChem. 2015, 16, 978-985.

[49] V. Sladek, P. Škorňa, P. Poliak, V. Lukeš, Chem. Phys. Lett. 2015, 619, 7-13.

[50] A. Li, H. S. Muddana, M. K. Gilson, J. Chem. Theory Comput. 2014, 10, 1563-1575.

[51] A. Forni, S. Pieraccini, S. Rendine, M. Sironi, jJournal of Computational Chemistry 2014, 35, 386394.

[52] A. Bauzá, I. Alkorta, A. Frontera, J. Elguero, J. Chem. Theory Comput. 2013, 9, 5201-5210.

[53] M. Walker, A. J. A. Harvey, A. Sen, C. E. H. Dessent, J. Phys. Chem. A 2013, 117, 12590-12600.

[54] N. Mardirossian, M. Head-Gordon, J. Chem. Theory Comput. 2013, 9, 4453-4461.

[55] J. Elm, M. Bildeb, K. V. Mikkelsena, Phys. Chem. Chem. Phys. 2013, 15, 16442-16445.

[56] G. A. DiLabio, E. R. Johnson, A. Otero-de-la-Roza, Phys. Chem. Chem. Phys. 2013, 15, 1282112828.

[57] S. V. Rosokha, C. L. Stern, J. T. Ritzert, Chem. Eur. J. 2013, 19, 8774-8788.

[58] B. Nepal, S. Scheiner, Chem. Eur. J. 2015, 21, 13330-13335.

[59] S. F. Boys, F. Bernardi, Mol. Phys. 1970, 19, 553-566.

[60] V. Barone, M. Cossi, J. Phys. Chem. A 1998, 102, 1995-2001.

[61] F. A. Bulat, A. Toro-Labbé, T. Brinck, J. S. Murray, P. Politzer, J. Mol. Model. 2010, 16, 16791691.

[62] E. D. Glendening, C. R. Landis, F. Weinhold, J. Comput. Chem. 2013, 34, 1429-1437. 
Table 1. Counterpoise-corrected binding energies $(\mathrm{kcal} / \mathrm{mol})$ of the complexes of bis-imidazolium and bistriazolium based anion receptors with halide anions.

\begin{tabular}{|c|c|c|c|c|c|c|c|c|c|c|c|c|}
\hline \multicolumn{13}{|c|}{ bis-imidazolium } \\
\hline \multirow[t]{2}{*}{$\mathrm{Y}^{-}$} & \multicolumn{3}{|c|}{ Benzene } & \multicolumn{3}{|c|}{ thiophene } & \multicolumn{3}{|c|}{ carbazole } & \multicolumn{3}{|c|}{ dimethylnaphthalene } \\
\hline & $2 \mathrm{H}$ & $2 \mathrm{Br}$ & 21 & $2 \mathrm{H}$ & $2 \mathrm{Br}$ & 21 & $2 \mathrm{H}$ & $2 \mathrm{Br}$ & 21 & $2 \mathrm{H}$ & $2 \mathrm{Br}$ & 21 \\
\hline $\mathrm{F}^{-}$ & 19.07 & 17.76 & 25.06 & 15.01* & 14.80 & 24.05 & $12.29 *$ & $10.51^{*}$ & 24.33 & $11.46^{*}$ & 16.61 & 27.51 \\
\hline $\mathrm{Cl}^{-}$ & 10.43 & 11.25 & 16.11 & $5.81^{*}$ & 9.23 & 15.14 & $6.49 *$ & 8.03 & 13.54 & 10.12 & 10.59 & 15.86 \\
\hline $\mathrm{Br}^{-}$ & 9.21 & 10.61 & 15.33 & 5.93 & 8.83 & 14.33 & 6.59 & 7.81 & 12.70 & 9.62 & 10.16 & 14.72 \\
\hline $\mathrm{I}^{-}$ & 7.99 & 10.33 & 14.43 & 6.02 & 8.40 & 13.47 & 6.64 & 7.54 & 11.86 & 9.18 & 9.54 & 13.66 \\
\hline \multicolumn{13}{|c|}{ bis-triazolium } \\
\hline \multirow[t]{2}{*}{$\mathrm{Y}^{-}$} & \multicolumn{3}{|c|}{ Benzene } & \multicolumn{3}{|c|}{ thiophene } & \multicolumn{3}{|c|}{ carbazole } & \multicolumn{3}{|c|}{ dimethylnaphthalene } \\
\hline & $2 \mathrm{H}$ & $2 \mathrm{Br}$ & 21 & $2 \mathrm{H}$ & $2 \mathrm{Br}$ & 21 & $2 \mathrm{H}$ & $2 \mathrm{Br}$ & 21 & $2 \mathrm{H}$ & $2 \mathrm{Br}$ & 21 \\
\hline$F^{-}$ & 15.19 & 16.39 & 23.35 & $11.48^{*}$ & $10.96 *$ & 20.80 & $9.82 *$ & 12.98 & $17.36^{*}$ & $9.97^{*}$ & 16.91 & 27.61 \\
\hline $\mathrm{Cl}^{-}$ & 8.23 & 10.59 & 15.00 & $5.22 *$ & 7.20 & 12.82 & $5.40 *$ & 8.22 & 13.81 & 7.57 & 10.09 & 15.15 \\
\hline $\mathrm{Br}^{-}$ & 7.29 & 10.04 & 14.21 & $4.52 *$ & 7.20 & 12.28 & 5.47 & 7.93 & 12.95 & 7.11 & 9.51 & 14.01 \\
\hline $\mathrm{I}^{-}$ & 6.45 & 9.41 & 13.35 & $4.60 *$ & 7.22 & 11.70 & 5.50 & 7.74 & 12.10 & 6.83 & 8.87 & 12.82 \\
\hline
\end{tabular}

*asymmetric binding of halide

Table 2. Optimized distances $(\AA)$ from anion to $\mathrm{H}$ or halogen atoms.

\begin{tabular}{|c|c|c|c|c|c|c|c|c|c|c|c|c|}
\hline \multicolumn{13}{|c|}{ bis-imidazolium } \\
\hline \multirow[t]{2}{*}{$\mathrm{Y}^{-}$} & \multicolumn{3}{|c|}{ Benzene } & \multicolumn{3}{|c|}{ thiophene } & \multicolumn{3}{|c|}{ carbazole } & \multicolumn{3}{|c|}{ dimethylnaphthalene } \\
\hline & $2 \mathrm{H}$ & $2 \mathrm{Br}$ & 21 & $2 \mathrm{H}$ & $2 \mathrm{Br}$ & 21 & $2 \mathrm{H}$ & $2 \mathrm{Br}$ & 21 & $2 \mathrm{H}$ & $2 \mathrm{Br}$ & 21 \\
\hline $\mathrm{F}^{-}$ & 1.768 & 2.486 & 2.509 & $1.034^{*}$ & 2.491 & 2.498 & $1.515^{*}$ & $2.354^{*}$ & 2.449 & $1.597^{*}$ & 2.468 & 2.440 \\
\hline $\mathrm{Cl}^{-}$ & 2.361 & 3.078 & 3.101 & $2.369 *$ & 3.105 & 3.097 & $2.472^{*}$ & 3.148 & 3.088 & 2.447 & 3.092 & 3.072 \\
\hline $\mathrm{Br}^{-}$ & 2.535 & 3.237 & 3.259 & 2.898 & 3.264 & 3.257 & 2.936 & 3.303 & 3.260 & 2.637 & 3.250 & 3.242 \\
\hline $\mathrm{I}^{-}$ & 2.787 & 3.449 & 3.473 & 3.108 & 3.480 & 3.472 & 3.074 & 3.521 & 3.484 & 2.856 & 3.463 & 3.466 \\
\hline \multicolumn{13}{|c|}{ bis-triazolium } \\
\hline \multirow[t]{2}{*}{$\mathrm{Y}^{-}$} & \multicolumn{3}{|c|}{ Benzene } & \multicolumn{3}{|c|}{ thiophene } & \multicolumn{3}{|c|}{ carbazole } & \multicolumn{3}{|c|}{ dimethylnaphthalene } \\
\hline & $2 \mathrm{H}$ & $2 \mathrm{Br}$ & 21 & $2 \mathrm{H}$ & $2 \mathrm{Br}$ & 21 & $2 \mathrm{H}$ & $2 \mathrm{Br}$ & 21 & $2 \mathrm{H}$ & $2 \mathrm{Br}$ & 21 \\
\hline $\mathrm{F}^{-}$ & 1.798 & 2.504 & 2.521 & 1.424* & 2.334* & 2.516 & 1.516* & 2.503 & $2.281^{*}$ & $1.571^{*}$ & 2.464 & 2.432 \\
\hline $\mathrm{Cl}^{-}$ & 2.431 & 3.095 & 3.123 & 2.329* & 3.196 & 3.133 & $2.572 *$ & 3.143 & 3.106 & 2.455 & 3.083 & 3.079 \\
\hline $\mathrm{Br}^{-}$ & 2.627 & 3.252 & 3.277 & $2.864^{*}$ & 3.359 & 3.296 & 3.013 & 3.305 & 3.272 & 2.646 & 3.248 & 3.246 \\
\hline $1^{-}$ & 2.883 & 3.467 & 3.489 & 3.209* & 3.566 & 3.509 & 3.131 & 3.530 & 3.496 & 2.880 & 3.466 & 3.473 \\
\hline
\end{tabular}

*asymmetric binding of halide 
Table 3. $\mathrm{CH}^{\cdots} \mathrm{Y}^{-}$or $\mathrm{CX}^{\cdots} \mathrm{Y}^{-}$bond angles (degs).

\begin{tabular}{|c|c|c|c|c|c|c|c|c|c|c|c|c|}
\hline \multicolumn{13}{|c|}{ bis-imidazolium } \\
\hline \multirow[t]{2}{*}{$\mathrm{Y}^{-}$} & \multicolumn{3}{|c|}{ Benzene } & \multicolumn{3}{|c|}{ thiophene } & \multicolumn{3}{|c|}{ carbazole } & \multicolumn{3}{|c|}{ dimethylnaphthalene } \\
\hline & $2 \mathrm{H}$ & $2 \mathrm{Br}$ & 21 & $2 \mathrm{H}$ & $2 \mathrm{Br}$ & 21 & $2 \mathrm{H}$ & $2 \mathrm{Br}$ & 21 & $2 \mathrm{H}$ & $2 \mathrm{Br}$ & 21 \\
\hline$F^{-}$ & 167.0 & 170.9 & 166.0 & $176.5^{*}$ & 170.2 & 167.0 & $174.8^{*}$ & $179.9 *$ & 177.1 & $159.2^{*}$ & 177.7 & 178.9 \\
\hline $\mathrm{Cl}^{-}$ & 170.1 & 174.3 & 169.7 & 153.9* & 170.3 & 170.1 & $161.1^{*}$ & 171.1 & 177.0 & 155.1 & 174.6 & 179.4 \\
\hline $\mathrm{Br}^{-}$ & 169.4 & 175.1 & 170.4 & 146.5 & 170.6 & 170.5 & 159.5 & 171.2 & 176.5 & 155.9 & 174.5 & 178.9 \\
\hline $\mathrm{I}^{-}$ & 161.4 & 176.3 & 171.6 & 145.7 & 170.7 & 171.2 & 161.5 & 170.1 & 176.2 & 157.5 & 173.8 & 178.3 \\
\hline \multicolumn{13}{|c|}{ bis-triazolium } \\
\hline \multirow[t]{2}{*}{$\mathrm{Y}^{-}$} & \multicolumn{3}{|c|}{ Benzene } & \multicolumn{3}{|c|}{ thiophene } & \multicolumn{3}{|c|}{ carbazole } & \multicolumn{3}{|c|}{ dimethylnaphthalene } \\
\hline & $2 \mathrm{H}$ & $2 \mathrm{Br}$ & 21 & $2 \mathrm{H}$ & $2 \mathrm{Br}$ & 21 & $2 \mathrm{H}$ & $2 \mathrm{Br}$ & 21 & $2 \mathrm{H}$ & $2 \mathrm{Br}$ & 21 \\
\hline $\mathrm{F}^{-}$ & 159.9 & 170.1 & 165.6 & $179.8^{*}$ & $179.8^{*}$ & 166.1 & $177.6^{*}$ & 175.4 & $179.7^{*}$ & $171.3^{*}$ & 179.0 & 177.3 \\
\hline $\mathrm{Cl}^{-}$ & 159.2 & 173.3 & 169.3 & $171.8^{*}$ & 162.5 & 168.2 & $153.6^{*}$ & 172.9 & 176.6 & 168.8 & 179.3 & 178.5 \\
\hline $\mathrm{Br}^{-}$ & 156.3 & 174.3 & 170.1 & $122.6^{*}$ & 162.1 & 168.4 & 151.6 & 172.7 & 176.7 & 166.8 & 178.1 & 178.6 \\
\hline $1^{-}$ & 151.9 & 175.4 & 171.3 & $117.6^{*}$ & 162.3 & 168.8 & 155.8 & 171.8 & 176.5 & 168.2 & 179.0 & 178.6 \\
\hline
\end{tabular}

*asymmetric binding of halide

Table 4. $\theta\left(\mathrm{H}^{*} \mathrm{Y}^{-\cdot \cdot \mathrm{H})} / \mathrm{\theta}\left(\mathrm{X} \cdot \mathrm{Y}^{-\cdot \cdot \mathrm{X})}\right.\right.$ angles (degs).

\begin{tabular}{|c|c|c|c|c|c|c|c|c|c|c|c|c|}
\hline \multicolumn{13}{|c|}{ bis-imidazolium } \\
\hline \multirow[t]{2}{*}{$\mathrm{Y}^{-}$} & \multicolumn{3}{|c|}{ Benzene } & \multicolumn{3}{|c|}{ thiophene } & \multicolumn{3}{|c|}{ carbazole } & \multicolumn{3}{|c|}{ dimethylnaphthalene } \\
\hline & $2 \mathrm{H}$ & $2 \mathrm{Br}$ & 21 & $2 \mathrm{H}$ & $2 \mathrm{Br}$ & 21 & $2 \mathrm{H}$ & $2 \mathrm{Br}$ & 21 & $2 \mathrm{H}$ & $2 \mathrm{Br}$ & 21 \\
\hline $\mathrm{F}^{-}$ & 127.0 & 87.9 & 91.6 & - & 94.5 & 95.7 & - & - & 111.4 & - & 123.1 & 115.2 \\
\hline $\mathrm{Cl}^{-}$ & 103.4 & 74.4 & 76.9 & - & 84.0 & 81.9 & - & 110.9 & 99.3 & 130.0 & 115.6 & 103.8 \\
\hline $\mathrm{Br}^{-}$ & 95.9 & 71.3 & 73.8 & 115.2 & 81.4 & 79.2 & 147.4 & 107.7 & 97.2 & 125.1 & 114.0 & 104.3 \\
\hline $\mathrm{I}^{-}$ & 85.8 & 67.4 & 69.9 & 109.7 & 78.4 & 75.6 & 140.0 & 104.5 & 93.9 & 123.1 & 112.3 & 102.3 \\
\hline \multicolumn{13}{|c|}{ bis-triazolium } \\
\hline \multirow[t]{2}{*}{$\mathrm{Y}^{-}$} & \multicolumn{3}{|c|}{ Benzene } & \multicolumn{3}{|c|}{ thiophene } & \multicolumn{3}{|c|}{ carbazole } & \multicolumn{3}{|c|}{ dimethylnaphthalene } \\
\hline & $2 \mathrm{H}$ & $2 \mathrm{Br}$ & 21 & $2 \mathrm{H}$ & $2 \mathrm{Br}$ & 21 & $2 \mathrm{H}$ & $2 \mathrm{Br}$ & 21 & $2 \mathrm{H}$ & $2 \mathrm{Br}$ & 21 \\
\hline$F^{-}$ & 133.8 & 87.8 & 91.8 & - & - & 95.9 & - & 117.5 & - & - & 128.3 & 119.8 \\
\hline $\mathrm{Cl}^{-}$ & 114.4 & 74.6 & 77.1 & - & 90.7 & 82.7 & - & 108.0 & 98.9 & 135.4 & 121.0 & 111.4 \\
\hline $\mathrm{Br}^{-}$ & 109.9 & 71.5 & 74.1 & - & 88.6 & 80.3 & 154.7 & 105.0 & 96.1 & 129.6 & 118.7 & 109.2 \\
\hline $1^{-}$ & 100.9 & 67.7 & 70.2 & - & 85.4 & 76.9 & 147.5 & 101.8 & 93.0 & 126.7 & 113.0 & 105.1 \\
\hline
\end{tabular}


Table 5. $\theta(\mathrm{H} \cdot \mathrm{P} \cdot \mathrm{H}) / \theta(\mathrm{X} \cdot \mathrm{P} \cdot \mathrm{X})$ angle (degs) in the uncomplexed receptors where P represents the meeting point of $\mathrm{CH} / \mathrm{CX}$ bonds on the two binding species when elongated linearly.

\begin{tabular}{|c|c|c|c|c|c|c|c|c|c|c|c|c|}
\hline & \multicolumn{3}{|c|}{ Benzene } & \multicolumn{3}{|c|}{ thiophene } & \multicolumn{3}{|c|}{ carbazole } & \multicolumn{3}{|c|}{ dimethylnaphthalene } \\
\hline & $2 \mathrm{H}$ & $2 \mathrm{Br}$ & 21 & $2 \mathrm{H}$ & $2 \mathrm{Br}$ & 21 & $2 \mathrm{H}$ & $2 \mathrm{Br}$ & 21 & $2 \mathrm{H}$ & $2 \mathrm{Br}$ & 21 \\
\hline imidazolium & 75.7 & 55.4 & 47.8 & 53.8 & 35.8 & 38.7 & 84.9 & 18.4 & 44.7 & 157.0 & 90.4 & 89.6 \\
\hline triazolium & 56.4 & 55.1 & 43.9 & 41.2 & 36.3 & 33.4 & 72.3 & 67.4 & 63.7 & 117.4 & 115.9 & 123.7 \\
\hline
\end{tabular}

Table 6. Dihedral angles (degs) between the spacer group and imidazolium/triazolium in uncomplexed and complexed receptors.

\begin{tabular}{|c|c|c|c|c|c|c|c|c|c|c|c|c|}
\hline \multicolumn{13}{|c|}{ bis-imidazolium } \\
\hline & \multicolumn{3}{|c|}{ Benzene } & \multicolumn{3}{|c|}{ thiophene } & \multicolumn{3}{|c|}{ carbazole } & \multicolumn{3}{|c|}{ dimethylnaphthalene } \\
\hline & $2 \mathrm{H}$ & $2 \mathrm{Br}$ & 21 & $2 \mathrm{H}$ & $2 \mathrm{Br}$ & 21 & $2 \mathrm{H}$ & $2 \mathrm{Br}$ & 21 & $2 \mathrm{H}$ & $2 \mathrm{Br}$ & 21 \\
\hline Monomer & 44.4 & 62.8 & 75.2 & 55.5 & 92.9 & 88.7 & 47.5 & 71.1 & 100.5 & 61.2 & 52.7 & 56.3 \\
\hline $\mathrm{F}^{-}$ & 24.0 & 54.5 & 62.7 & $1.3^{*}$ & 74.0 & 77.8 & $16.2^{*}$ & $60.4^{*}$ & 50.8 & $66.8^{*}$ & 41.4 & 42.6 \\
\hline $\mathrm{Cl}^{-}$ & 34.9 & 57.6 & 64.2 & $75.5^{*}$ & 74.8 & 78.2 & $29.4^{*}$ & 51.7 & 52.9 & 56.5 & 40.9 & 41.6 \\
\hline $\mathrm{Br}^{-}$ & 35.5 & 57.9 & 65.2 & 62.8 & 75.0 & 78.3 & 32.3 & 52.5 & 54.0 & 60.4 & 42.7 & 45.5 \\
\hline $\mathrm{I}^{-}$ & 36.2 & 58.7 & 66.5 & 64.7 & 75.6 & 79.0 & 34.7 & 53.7 & 54.5 & 61.0 & 46.2 & 47.1 \\
\hline \multicolumn{13}{|c|}{ bis-triazolium } \\
\hline & \multicolumn{3}{|c|}{ Benzene } & \multicolumn{3}{|c|}{ thiophene } & \multicolumn{3}{|c|}{ carbazole } & \multicolumn{3}{|c|}{ dimethylnaphthalene } \\
\hline & $2 \mathrm{H}$ & $2 \mathrm{Br}$ & 21 & $2 \mathrm{H}$ & $2 \mathrm{Br}$ & 21 & $2 \mathrm{H}$ & $2 \mathrm{Br}$ & 21 & $2 \mathrm{H}$ & $2 \mathrm{Br}$ & 21 \\
\hline Monomer & 46.7 & 50.6 & 55.8 & 37.2 & 44.4 & 55.9 & 45.0 & 50.0 & 52.0 & 78.1 & 64.4 & 68.6 \\
\hline $\mathrm{F}^{-}$ & 21.0 & 44.5 & 51.1 & $31.5^{*}$ & 42.7 & 57.0 & $36.0^{*}$ & 37.6 & 47.8 & 70.9* & 69.1 & 69.9 \\
\hline $\mathrm{Cl}^{-}$ & 35.3 & 46.5 & 52.0 & $34.8^{*}$ & 38.5 & 50.8 & $28.7^{*}$ & 40.6 & 42.8 & 62.9 & 72.2 & 64.3 \\
\hline $\mathrm{Br}^{-}$ & 40.1 & 46.5 & 52.3 & $49.4^{*}$ & 37.7 & 50.0 & 30.7 & 41.6 & 43.5 & 66.2 & 65.2 & 65.4 \\
\hline $1^{-}$ & 42.0 & 47.5 & 52.6 & $43.7^{*}$ & 37.5 & 48.6 & 32.9 & 43.4 & 44.1 & 67.6 & 65.5 & 65.4 \\
\hline
\end{tabular}

*asymmetric binding of halide 
Table 7. Maximum in the MEP $(\mathrm{kcal} / \mathrm{mol})$ on the $0.001 \mathrm{au}$ isodensity surface at the binding site of the receptor

\begin{tabular}{|l|l|l|l|l|l|l|l|l|l|l|l|l|l|}
\hline & \multicolumn{4}{|l|}{ Benzene } & \multicolumn{3}{l|}{ thiophene } & \multicolumn{3}{l|}{ carbazole } & \multicolumn{3}{l|}{ dimethylnaphthalene } \\
\cline { 2 - 13 } & $2 \mathrm{H}$ & $2 \mathrm{Br}$ & $2 \mathrm{I}$ & $2 \mathrm{H}$ & $2 \mathrm{Br}$ & $2 \mathrm{I}$ & $2 \mathrm{H}$ & $2 \mathrm{Br}$ & $2 \mathrm{I}$ & $2 \mathrm{H}$ & $2 \mathrm{Br}$ & $2 \mathrm{I}$ \\
\hline imidazolium & 197.6 & 159.7 & 161.2 & 182.3 & 148.6 & 156.2 & 168.5 & 135.6 & 137.0 & 171.3 & 144.2 & 151.7 \\
\hline triazolium & 184.0 & 152.9 & 156.6 & 175.1 & 144.2 & 148.9 & 162.3 & 136.5 & 143.0 & $--\mathrm{a}^{\mathrm{a}}$ & 143.5 & 159.7 \\
\hline
\end{tabular}

a binding site on $\mathrm{H}$ not among 20 highest maxima.

Table 8. NBO values of $\mathrm{E}(2)(\mathrm{kcal} / \mathrm{mol})$ for charge transfer from halide to $\mathrm{CH} / \mathrm{CX} \sigma^{*}$ antibonding orbitals of imidazolium or triazolium

\begin{tabular}{|c|c|c|c|c|c|c|c|c|c|c|c|c|}
\hline \multicolumn{13}{|c|}{ bis-imidazolium } \\
\hline \multirow[t]{2}{*}{$\mathrm{Y}^{-}$} & \multicolumn{3}{|c|}{ Benzene } & \multicolumn{3}{|c|}{ thiophene } & \multicolumn{3}{|c|}{ carbazole } & \multicolumn{3}{|c|}{ dimethylnaphthalene } \\
\hline & $2 \mathrm{H}$ & $2 \mathrm{Br}$ & 21 & $2 \mathrm{H}$ & $2 \mathrm{Br}$ & 21 & $2 \mathrm{H}$ & $2 \mathrm{Br}$ & 21 & $2 \mathrm{H}$ & $2 \mathrm{Br}$ & 21 \\
\hline $\mathrm{F}^{-}$ & 63.12 & 30.58 & 50.50 & $--^{b}$ & 30.43 & 52.84 & 69.17 & 24.91 & 63.56 & $48.72^{a}$ & 32.58 & 64.51 \\
\hline $\mathrm{Cl}^{-}$ & 36.15 & 18.19 & 34.22 & 15.34 & 16.62 & 34.97 & 18.52 & 14.58 & 36.89 & $31.70^{\mathrm{a}}$ & 17.19 & 38.25 \\
\hline $\mathrm{Br}^{-}$ & 31.49 & 16.59 & 32.01 & 10.10 & 15.20 & 32.50 & 16.60 & 13.46 & 32.75 & $27.54^{a}$ & 15.66 & 34.23 \\
\hline $\mathrm{I}^{-}$ & 27.26 & 15.73 & 30.90 & 9.84 & 14.20 & 30.97 & 17.43 & 12.44 & 30.50 & $26.35^{a}$ & 14.66 & 31.75 \\
\hline \multicolumn{13}{|c|}{ bis-triazolium } \\
\hline \multirow[t]{2}{*}{$\mathrm{Y}^{-}$} & \multicolumn{3}{|c|}{ Benzene } & \multicolumn{3}{|c|}{ thiophene } & \multicolumn{3}{|c|}{ carbazole } & \multicolumn{3}{|c|}{ dimethylnaphthalene } \\
\hline & $2 \mathrm{H}$ & $2 \mathrm{Br}$ & 21 & $2 \mathrm{H}$ & $2 \mathrm{Br}$ & 21 & $2 \mathrm{H}$ & $2 \mathrm{Br}$ & 21 & $2 \mathrm{H}$ & $2 \mathrm{Br}$ & 21 \\
\hline $\mathrm{F}^{-}$ & 54.49 & 28.42 & 48.02 & 85.34 & 26.55 & 49.56 & 61.56 & 29.35 & 55.44 & 51.84 & 32.79 & 64.88 \\
\hline $\mathrm{Cl}^{-}$ & 25.86 & 16.64 & 31.08 & 17.79 & 11.36 & 30.24 & 14.98 & 14.58 & 33.61 & 24.11 & 17.41 & 36.04 \\
\hline $\mathrm{Br}^{-}$ & 20.27 & 15.23 & 29.22 & 2.90 & 10.20 & 27.66 & 13.80 & 13.09 & 30.26 & 19.91 & 15.41 & 32.77 \\
\hline $\mathrm{I}^{-}$ & 16.05 & 14.18 & 28.05 & 1.64 & 9.80 & 26.33 & 13.48 & 11.79 & 27.87 & 18.05 & 14.22 & 29.24 \\
\hline
\end{tabular}

${ }^{a}$ Also includes charge transfer from halide to $\sigma^{*}(\mathrm{CH})$ antibonding orbitals of methyl group of imidazolium ${ }^{b} \mathrm{NBO}$ treats this complex as a single molecule instead of two monomers due to strength of interaction. 


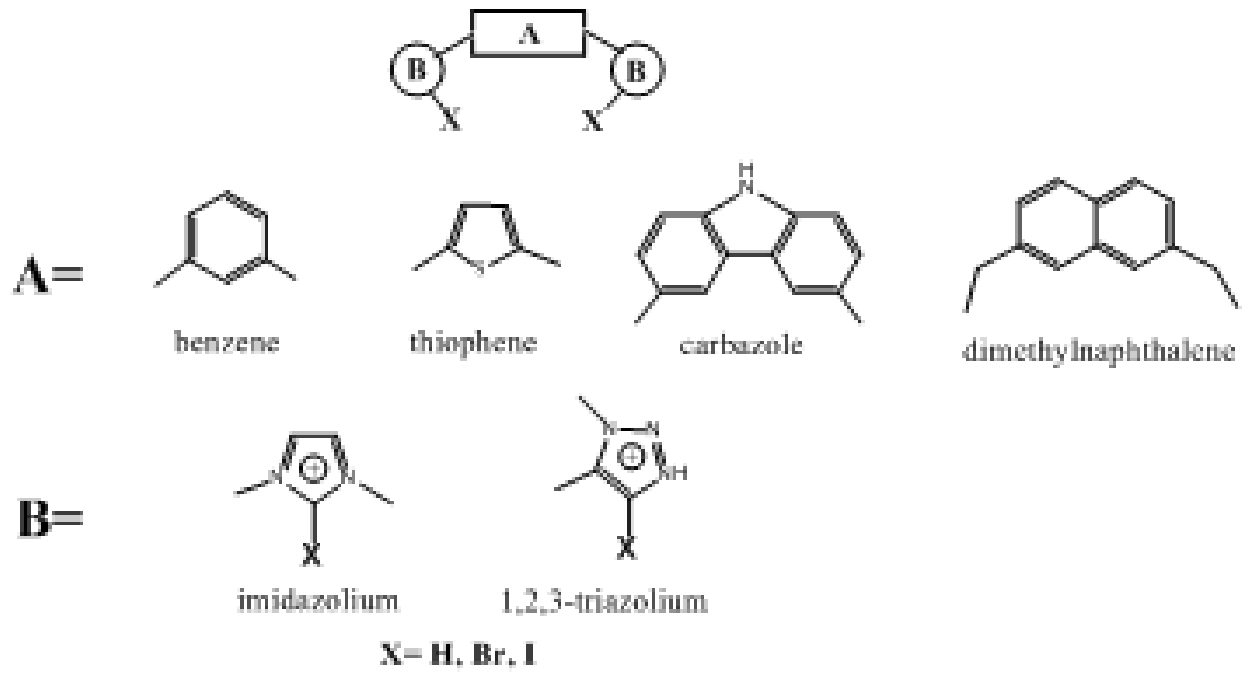

Scheme I. Composition of dicationic receptors. A represents one of four spacer groups, and B either an imidazolium or triazolium cation. Each of the latter cation can have a $\mathrm{H}, \mathrm{Br}$, or I atom at the indicated $\mathrm{X}$ position. 

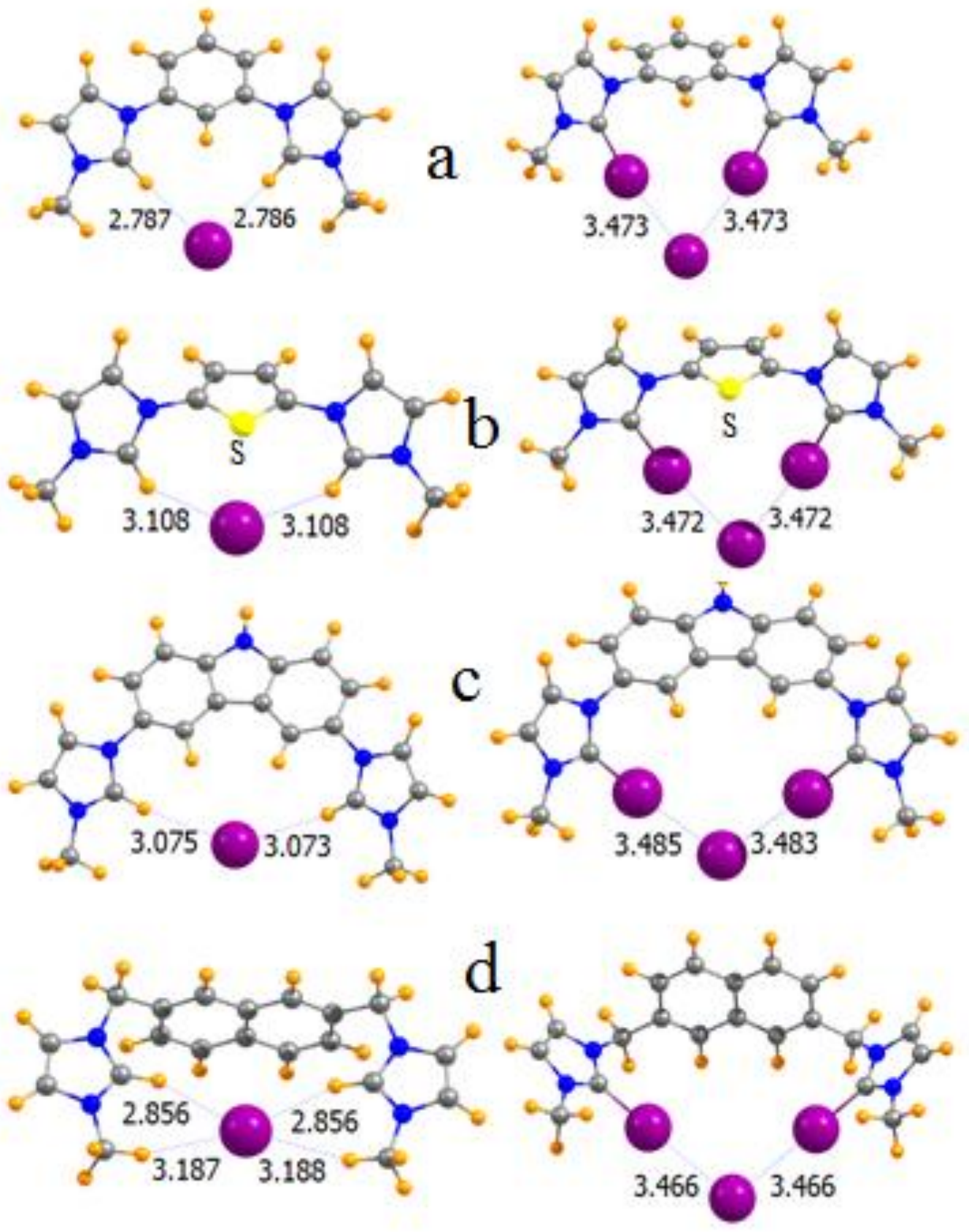

Fig 1. Optimized geometries of imidazolium complexes with $\mathrm{I}^{-}$. Spacers are a) benzene, b) thiophene, c) carbazole, and d) dimethylnaphthalene. $\mathrm{X}=\mathrm{H}$ shown on the left and $\mathrm{X}=\mathrm{I}$ on the right. 


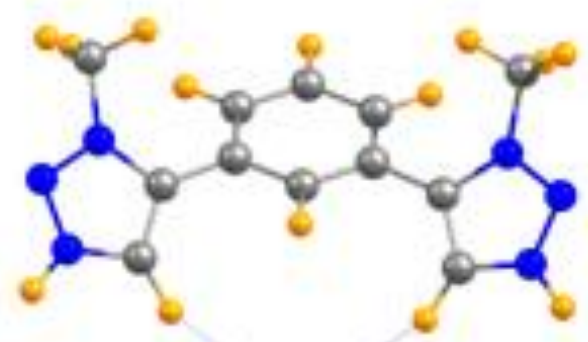

2.883

2.883 a

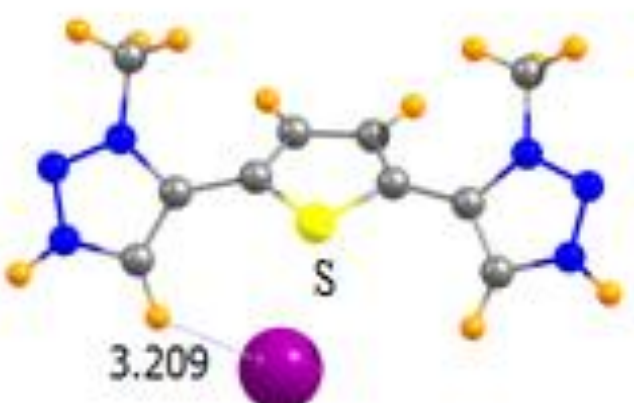

$\mathrm{b}$

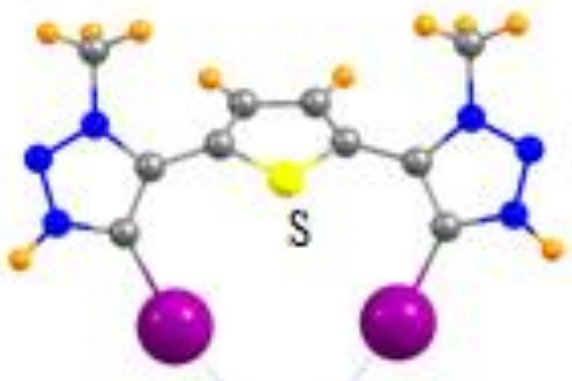

3.511

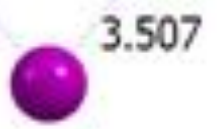

$\mathrm{C}$

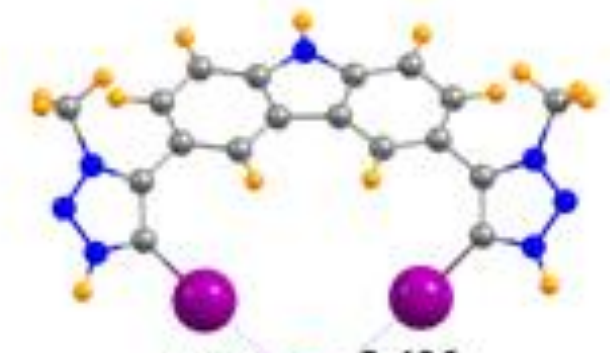

3.496

3.496

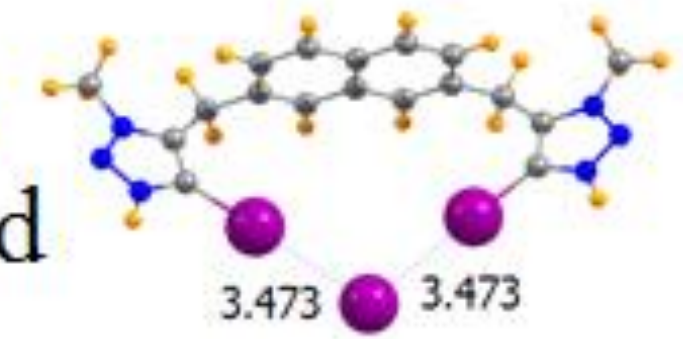

Fig 2. Optimized geometries of triazolium complexes with $\mathrm{I}^{-}$. Spacers are a) benzene, b) thiophene, c) carbazole, and d) dimethylnaphthalene. $\mathrm{X}=\mathrm{H}$ shown on the left and $\mathrm{X}=\mathrm{I}$ on the right. 


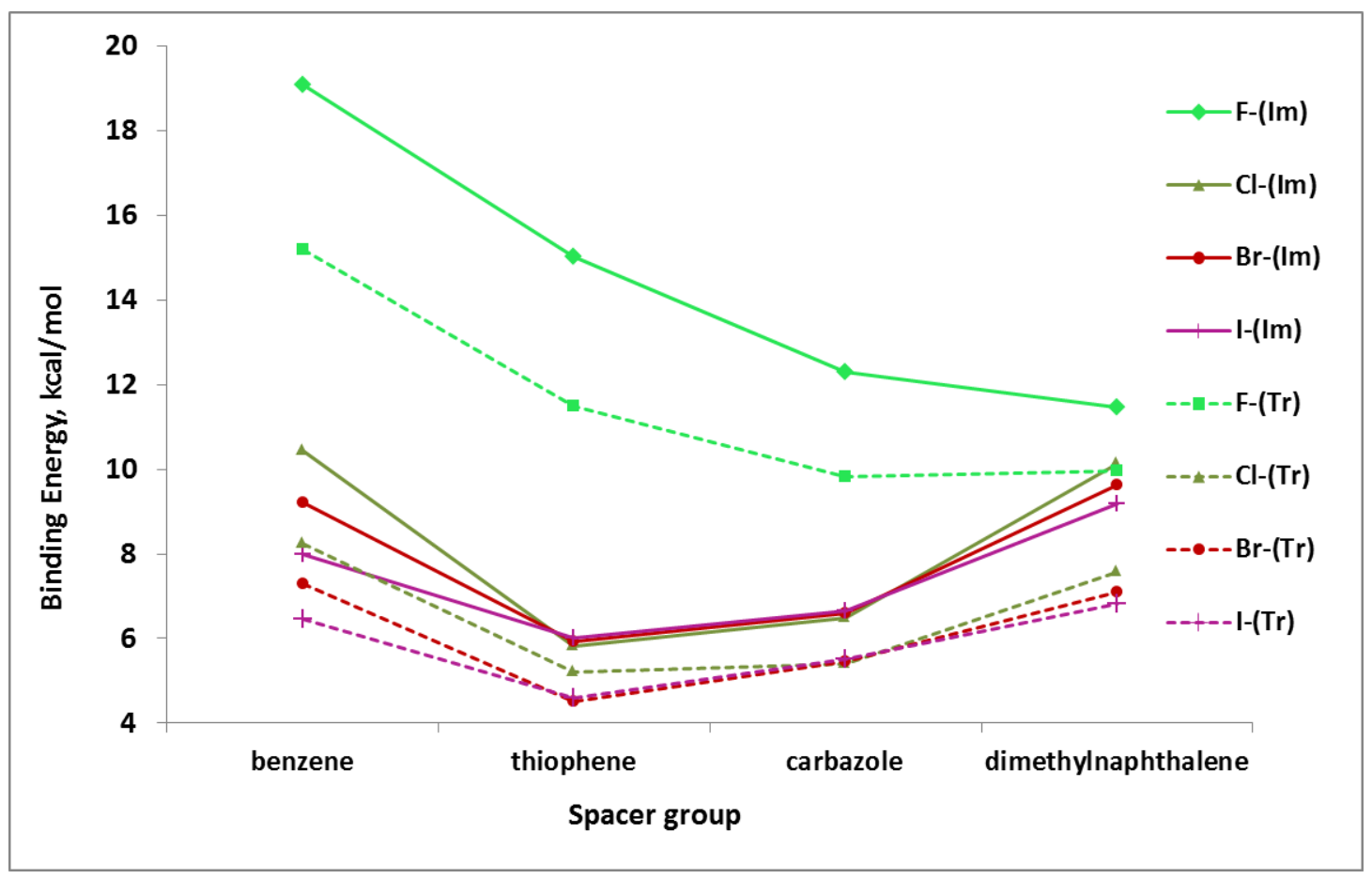

Fig 3. Binding energies of halides with H-bonding dicationic receptors with different spacers. Solid/broken lines indicate receptors containing imidazolium/triazolium. 


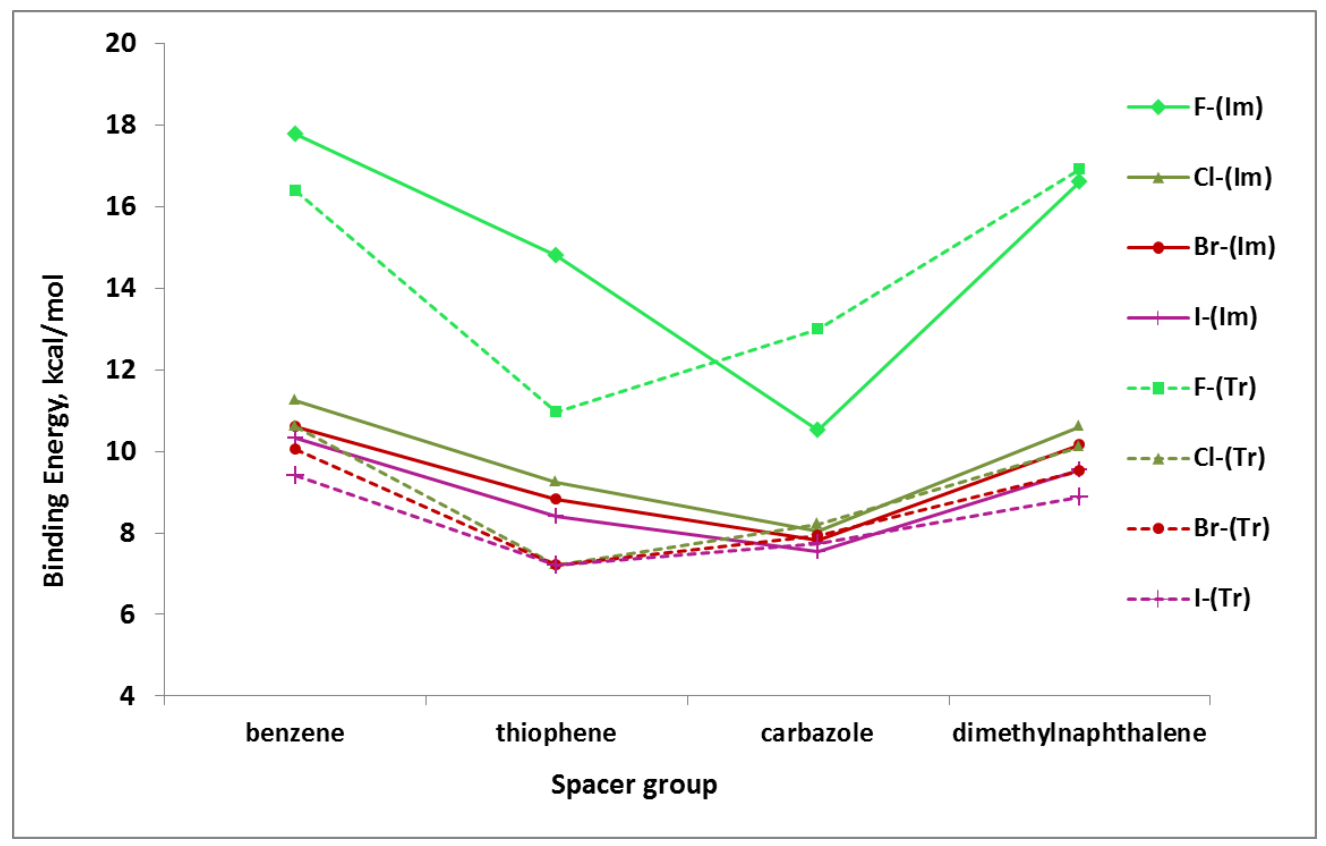

Fig 4. Binding energies of halides with Br-bonding dicationic receptors with different spacers. Solid/broken lines indicate receptors containing imidazolium/triazolium.

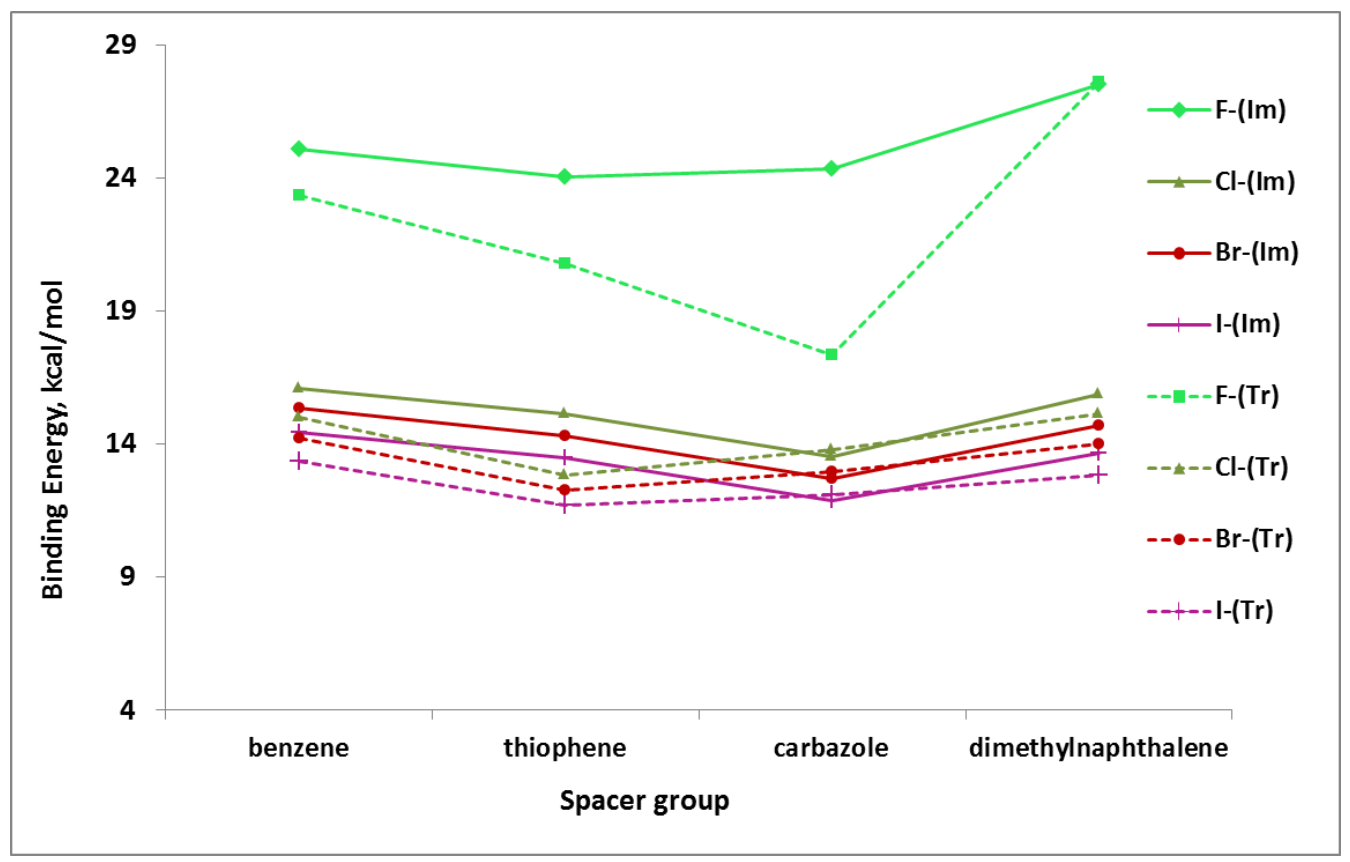

Fig 5. Binding energies of halides with I-bonding dicationic receptors with different spacers. Solid/broken lines indicate receptors containing imidazolium/triazolium. 


\section{I-bonds provide stronger halide binding than $\mathrm{H}$-bonds}
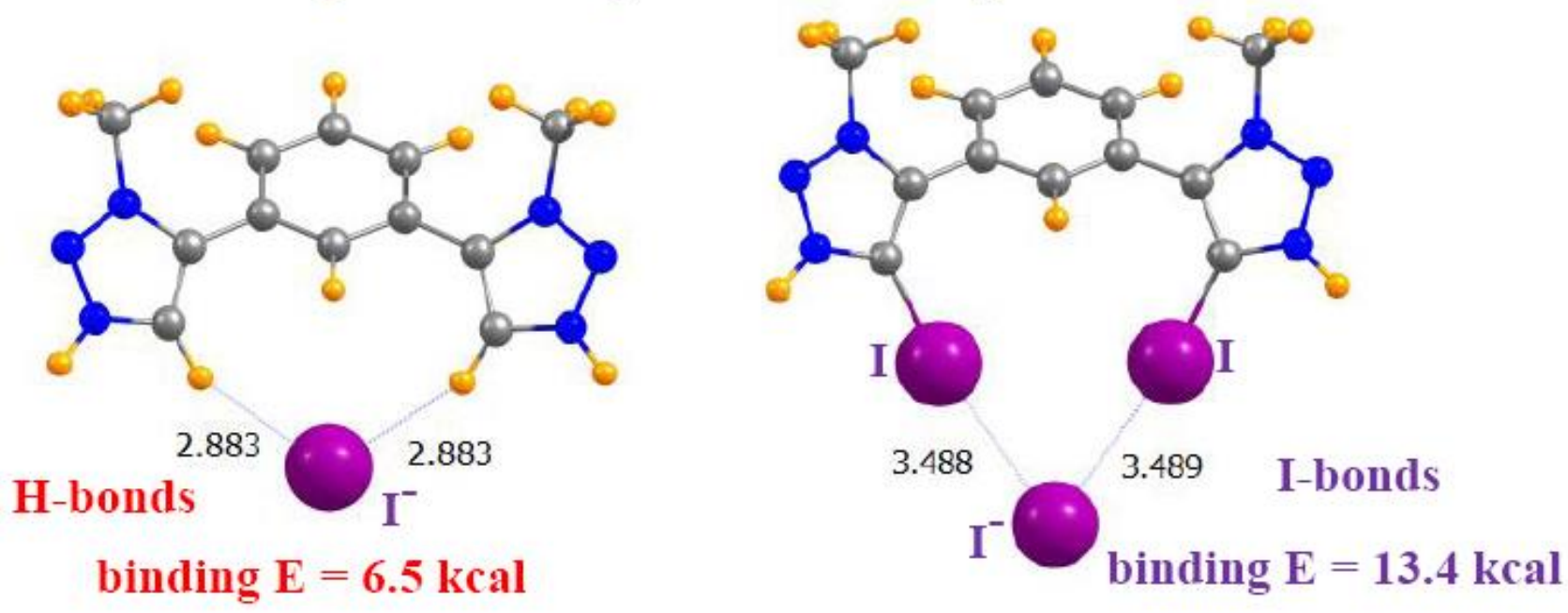

The replacement of $\mathrm{H}$ atoms on halide receptors by halogen atoms turns these $\mathrm{H}$-bonding receptors into halogen bonders. Quantum calculations assess how the binding strength is affected by i) the nature of the bonding group, ii) the identity of the spacer, iii) the charge on the receptor, and iv) the halogen used to replace $H$. 